Arch. Vet. Scienc. 3(1):95-100, 1998

Printed in Brazil

\title{
ANESTHESIA AND ANALGESIA IN ANTARCTIC FISH: AN EXPERIMENTAL APPROACH*
}

\section{WILMA PEREIRA BASTOS-RAMOS ${ }^{1}$; NEUZA M. F. M. GONÇALVES ${ }^{2}$; METRY BACILA $^{3}$}

Brazilian Antarctic Station Commander Ferraz, Admiralty Bay, King George Island, South Shetlands.

${ }^{1}$ Departamento de Ciências Fisiológicas, Faculdade de Odontologia, Universidade Estadual Paulista (UNESP), S. José dos Campos, S. Paulo, Brasil. ${ }^{2}$ Departamento de Medicina, Centro de Ciências Biológicas e da Saúde, Pontíficia Universidade Católica do Paraná - PUC-PR, Curitiba, Paraná, Brasil. ${ }^{3}$ Laboratório de Piscicultura, Departamento de Zootecnia, Universidade Federal do Paraná.

\begin{abstract}
It was studied in Antarctic fishes the anesthetic and/or analgesic actions of central depressors ketamine, fentanyl and thiopental as well as the local anesthetic benzocaine. The drugs were added to aerated marine water at temperatures of $1-1.5^{\circ} \mathrm{C}$. Ketamine $(15 \mathrm{mg} / \mathrm{L})$ and fentanyl $(50 \mu \mathrm{g} / \mathrm{L})$ failed in inducing anesthesia but caused a long lasting analgesia and sedation. Thiopental was required in doses of $100 \mathrm{mg} / \mathrm{L}$ to anesthetize the fishes, that is, about 30 times higher than the usual anesthetic dose for mammals. The anesthesia was long lasting, that is, 3-4 h, and difficult to control. One fish remained in a comatose state for four days with survival. Benzocaine in doses of $100 \mathrm{mg} / \mathrm{L}$ was successful in anesthetizing the fishes within 6-8 min, anesthesia lasting for 15-20 min, with a minor respiratory depression.
\end{abstract}

Key Words: Antarctic fish; Nototheniidae; benzocaine; fentanyl; ketamine; thiopental; analgesia; anesthesia.

RESUMO - Foi levado a efeito em peixes antárticos um estudo sobre as ações anestésicas e/ou analgésicas de depressores centrais ketamine, fentanyl e thiopental bem como do anestésico local benzocaina. As drogas foram adicionadas à água marinha aerada nas temperaturas de 1 a $1,5^{\circ} \mathrm{C}$. Ketamine $(15 \mathrm{mg} / \mathrm{L})$ e fentanyl $(50 \mu \mathrm{g} / \mathrm{L})$ não induziram anestesia mas causaram demorada analgesia e sedação. Doses de $100 \mathrm{mg} / \mathrm{L}$ de Thiopental foram necessárias para anestesiar peixes, ou seja, em concentração 30 vezes maior do que a dose anestésica usual utilizada para mamíferos. A anestesia ocasionada nos peixes foi longa - de 3 a 4 horas - e difícil de ser controlada. Um dos peixes utilizados na experimentação permaneceu em estado de comatose por quatro dias com sobrevida. Benzocaina em doses de $100 \mathrm{mg} / \mathrm{L}$ foi eficiente para anestesiar peixes dentro de 6 a 8 minutos após a sua administração. A anestesia, neste caso, teve duração de 15 a 20 minutos acompanhada de pequena depressão respiratória.

Palavras-Chave: Peixes Antárticos; Nototheniidae; benzocaine; fentanyl; ketamine; thiopental; analgesia; anestesia.

\section{Introduction}

Anesthesia of fishes is highly desirable in many occasions, such as for surgery operations, allowing a more careful and longer surgical procedure and an additional comfort to the researcher, not to say of an ethical attitude, avoiding pain and discomfort to the animal. Many anesthetic agents have been used in fishes of temperate regions. Drugs or maneuvers have been used either as experimental tool, or they have been studied in a comparative way regarding their efficacy and side effects. GILDERHUS and MARKING (1987) compared several anesthetic agents on rainbow trout in regard of induction and recovery times of anaesthesia: MS-222, quinaldine, benzocaine, 2-phenoxyethanol, methyl pentynol, chlorobutanol, etomidate, metomidate, propanidid, Piscaine, carbon dioxide, nicotine, Halothane, Methofane and Biotal. Other agents have been used, like Eugene, thiopental, ethanol (YAGITA and IKEDA, 1986; HIKASA et al., 1986, TAKASE et al., 1986) chlorobutanol (HANSEN and JOHNSSON,

\footnotetext{
*With a grant-in-aid from Brazilian Antarctic ProgramPROANTAR and CNPq Project \# 4.503.
}

1988), methomidate (IWAMA et al., 1989; MATTSON and RIPLE, 1989), sodium bicarbonate (JUAREZ-CASTRO et al., 1989), ketamine (GRAHAM and IWAMA, 1990; BRUECKER and GRAHAM, 1993), pregnolone, ether (OLIVER et al., 1991). For reviews on fish anesthesia see McFARLAND and KLONTZ (1969), RANDALL and HOAR (1971) and IWAMA et al. (1989).

McFARLAND and KLONTZ (1969) described the properties of many anesthetic drugs, the techniques of application and hazards of its use. It can be concluded that the responses of fishes to the various agents depend upon the species, the doses, the aim of the anesthesia and the physiological conditions of the fish. RANDALL and HOAR (1971) advise that more than one agent must be tried according the circumstances.

Maneuvers other than drugs have been used in the anesthesia of fishes, like electric anesthesia (ORSI and SHORT, 1987; CHIBA et al., 1990a; BARHAM and SCHOOMBEE, 1991a,b), $\mathrm{CO}_{2}$ (MITSUDA et al., 1988; YOSHIKAWA et al., 1991a,b). Electronarcose was used for the first time in a freshwater fish by STERRITT et al., (1994). 
Unanesthetized fishes suffer a great stress during catching, transporting or when submitted to manipulation, disturbance of its natural environment and when they undergo surgery. The stress and pain have important repercussions upon the physiological responses and biochemical profile, inducing endocrine and metabolic disturbance (ROBERTSON et al., 1988; MITSUDA et al., 1988; GINGERICH and DROTTAR, 1989; IWAMA et al., 1989; PUCÉAT et al., 1989; MORALES et al., 1990; CHIBA et al., 1990b; BARHAM and SCHOOMBEE, 1991a, b; THOMAS, 1991; RYAN, 1992; HUNN and GREER, 1991; BRADLEY and ANDERSON, 1992; BRUECKER and GRAHAM, 1993; FREDERICKS et al., 1993; YOKOHAMA et al., 1993; CHIBA and CHICHIBU, 1993; YOSHIKAWA et al., 1994). One could suppose that anesthesia of the fish could avoid biochemical and physiological disturbances due to stress. However, the anaesthetic drug can itself induce undesirable effects also distorting biochemical results. Tricaine mathanesulphonate (MS - 222) the most often used drug, leads to physiological and biochemical disturbances (CORNISH and MOON, 1986; ROBERTSON et al., 1988; LAIDLEY and LEATHERLAND, 1988; GINGERICH and DROTTAR, 1989; PUCÉAT et al., 1989; MORALES et al., 1990; RYAN, 1992; HUNN and GREER, 1991; SPOTTE et al., 1991; THOMAS, 1991) On the other hand, HUNN and GREER (1991) report no major changes in blood chemistry after anesthesia with tricaine and benzocaine and ROBERTSON et al., (1988) indicate anesthesia with MS-222 to avoid endocrine and metabolic changes due to stress. LOSEY and HUGIE (1994) refer to benefits of MS-222 over quinaldine and phenoxyethanol. McFARLAND and KLONTZ (1969) point out that "the decision whether or not to use an anaesthetic depends on the severity of the operation and its duration, and also on whether the stress resulting from the physical manipulation involved would create unwanted side effects. No strict guidelines can be laid down, but the advantages of anesthesia in minimizing stress and maximizing operative success usually are sufficient to warrant the use of anesthetics whenever possible."

Most of the authors have carried out their experiments using trouts, salmons and carps. Studies on the effects of anesthesia on the chemosensory behavior of Pacific salmon were carried out by QUINN and KONECKI (1988). Regarding to anesthesia of Antarctic fishes, only a few data were found. WELLS et al., (1984) refer to anesthesia of the giant Antarctic cod, Dissosthichus mawsoni and the nototheniid species Pagothenia borchgrevinki, using MS-
222. They observed $P$. borchgrenvinki during recovery from stress of capture and cannulation under MS-222. Cannulation with anesthesia resulted in a transient rise in hematocrit and hemoglobin concentration and a fall of blood $\mathrm{pH}$; these values returned to stable values 8-12 hours later. Severe stress resulted in a more marked increase in hemoglobin and hematocrit and a decrease in $\mathrm{pH}$. Erythrocytes appeared swollen and blood lactate was appreciably elevated, the blood profile returning to stable values 24 - $40 \mathrm{~h}$ after capture. Results with $P$. borchgrewinki indicated that erythrocyte swelling, elevated blood lactate and changes in ATP concentration were delayed manifestations of severe agitation stress. RYAN (1992) studied the susceptibility of Pagothenia borchgrevinki to MS-222 anesthesia and found that induction times were significantly longer than those of rainbow trout. Onset of anesthesia also failed to correlate with either brain or blood MS222 concentrations, in contrast to the trends observed in freshwater salmonids. The anesthesia was accompanied by dose-dependent changes in haematological parameters.

Our experiments with Antarctic fishes are usually invasive procedures, like inserting electrodes to measure oxygen consumption or for the recording of electrocardiogram, inserting needles to collect blood samples, and so on. These facts raised our interest in testing anaesthetic activity of some agents that are known to be effective in temperate water fishes and other drugs used to anesthetize mammals. So, we studied the following drugs: a) - Ketamine hydrochloride (2-[0chlorophenyl] 2 [methylamino] cyclohexanone hydrochloride) This arylcicloalkylamine induces in man a state of sedation, immobility, amnesia and an intense analgesia, marked by a patient strong feeling of dissociation of the environment, being called "dissociative anesthesia" (WINTERS et al., 1972). This drug was successfully used by GRAHAM and IWAMA (1990) to anesthetize two salmonids species and by BRUECKER and GRAHAM (1993) to anesthetize the fish Heros citrinellum. They used a dose of $30 \mathrm{mg} / \mathrm{kg}$ injected into the circulatory system. b) - Thiopental sodium (Pentothal) . This potent short acting barbiturate is used in man and other animals to induce a rapid anesthesia, with an onset of 10 to 20 seconds and duration of 20 to 30 minutes. The usual dose for man is $2.0-3.0 \mathrm{mg} / \mathrm{kg}$. TAKASE et al. (1986) used this drug dissolved in water in proportion of 200 to $300 \mathrm{ppm}$ to anesthetize Cyprynus carpio. c) Fentanyl. This synthetic opioid, chemically related with phenylpiperidine drugs (petidine group) is a powerful analgesic, being 50-100 times more potent than morphine, acting on $\mu$ opiate receptors. It is used in man to produce intense analgesia, in 
doses of 5 to $10 \mu \mathrm{g}$. Fentanyl in high doses and its derivatives alfentanyl and sulfentanyl induce general anesthesia with severe respiratory depression. When 50 to $100 \mu \mathrm{g}$ of fentanyl are injected intravenously, profound analgesia and unconsciousness are rapidly induced (KIHATA and COLLINS, 1982). d) - Benzocaine (ethyl - p aminobenzoate). It is an ester of para-aminobenzoic acid, identical to the local anaesthetic benzocaine, except that it lacks the terminal diethylamino group. The drug is poorly soluble in water, very slowly absorbed to be toxic to man. Benzocaine has been successfully used to anesthetize fresh water fishes, dissolved in water in proportion of $1 / 5,000$ or $1 / 10,000$. Temperature can influence the optimum concentration of benzocaine (PHARMA and CROUX, 1990).

\section{Material and Methods}

The fishes were caught at the Admiralty Bay, King George Island, South Shetlands, where the Antarctic Brazilian Station is settled, during the late Summer 1995. For the fishing, a bottom net was thrown at 40 to $100 \mathrm{~m}$ depth, there remaining 24 to 48 hours. For experiments 18 Notothenia neglecta $(30-50 \mathrm{~cm}), 3$ Notothenia rossii (40-45 $\mathrm{cm})$ and 4 Trematomous bernachii $(20-30 \mathrm{~cm})$ were selected.

Prior to the experiments, the fishes were kept in an aquarium with aerated marine water at the temperature of 0.5 to $1.5^{\circ} \mathrm{C}$ for at least 10 days. The water was changed once or twice a day and temperature, $\mathrm{pH}$ and salinity monitored. Until 48 hours before the experiments, the animals were offered fresh fish flesh slices. The feeding was not predictable, as it is usual with these fishes in aquarium conditions. To the experiments, the fishes were put to acclimation for 8 to 10 hours in individual tanks with aerated marine water. The behavior in such "normal" condition was considered as control. The anesthetic drug was dissolved in the water of the tanks in the concentration shown bellow. After a convincing result was obtained (anesthesia or other), the animal was returned to drug free aerated water to recover.

Anesthesia or analgesia testings. Groups of five fishes of either species were used to test ketamine, fentanyl and thiopental; 10 fishes were used to test benzocaine. The behavioral changes indicating the level of depression were observed after MCFARLAND and KLONTZ (1969), who described signals stepped as follows: normal; light sedation; deep sedation; partial loss of equilibrium; total loss of equilibrium; loss of reflex reactivity; medullar collapse. The depression level, according CHIBA et al., (1990a) are based in movements and respiratory status of the fish, meaning 1) sedative stage; 2) pre-anesthesia stage; 3) anesthesia stage and 4) paralysis stage. Such signs must be evaluated under the natural sluggish behavior of the Antarctic fish. They seem always depressed and the responses have to be provoked rather than expontaneous. Then, before adding drugs to the water, the fish was gently stimulated to swim. Analgesia was tested by tweezing the skin, inserting a needle into the tail muscle, sometimes transfixing it. Every fish was tested to painful stimulus before the administration of the drugs, as control. An initial trial of the doses, in order to assure a non lethal concentration, was carried out.

Drugs and doses. 1) Ketamine - The drug was added to the water in proportion of $15 \mathrm{mg} / \mathrm{L}$. The fishes were observed for $4.0 \mathrm{~h}$ and tested every 15 min for behavioral responses indicative of depression and analgesia.

2) Thiopental sodium - It was dissolved in the water in proportion of $100 \mathrm{mg} / \mathrm{L}$. The fishes were observed every $30 \mathrm{~min}$ up to $4.0-5.0 \mathrm{~h}$. One fish, in comatose state, was observed up to 5 days.

3) Fentanyl - Doses of $50 \mu \mathrm{g} / \mathrm{L}$ were used. The fishes were observed every $10 \mathrm{~min}$ regarding to analgesia and depression, up to $5.0 \mathrm{~h}$.

4) Benzocaine hydrochloride - The drug was used in concentration of $100 \mathrm{mg} / \mathrm{L}$. The fishes were observed for $30 \mathrm{~min}$ regarding to anesthesia.

\section{Results}

Ketamine - At 90-100 min after the drug, a slight depression could be observed. However, the fishes could swim or react vigorously when caught in a manual net and maintained the reflex of escaping to touch. Respiration was slightly depressed after $1 \mathrm{~h}$. However, analgesia, with no reaction to painful stimulus was observed within $30 \mathrm{~min}$ after the drug, lasting up to $2 \cdot 0-3,0 \mathrm{~h}$. No reaction on transfixing the tail with a needle or to tweezing the skin was interpreted as analgesia, since fishes are very sensitive to these stimulus.

Thiopental sodium - Doses of $100 \mathrm{mg} / \mathrm{L}$ caused anesthesia, very slow in onset: 1.30 to $2.00 \mathrm{~h}$, and lasting for 3.00 to $4.00 \mathrm{~h}$ followed by a slow recovery. During anesthesia, respiratory frequency dropped to 50 per cent, keeping about normal amplitude. One fish became comatose for 4 days. During the time it was completely unreactive, respiration was kept regular and depressed in about 30 per cent. At the 5th day, the fish was swimming, showing a good health, could be fed and survived.

Fentanyl - Doses of $50 \mu \mathrm{g} / \mathrm{ml}$ induced only a slight sedation within 15-20 min, but no anesthesia and no alteration of respiratory frequency. However, 
analgesia could be observed within 10-15 min, lasting up to 40 hours. The fish could swim when stimulated and the reflex of escaping at a touch was preserved. The fish did not react to tweezing the skin nor to inserting a needle through the tail.

Benzocaine hydrochloride - This drug, in doses of $100 \mathrm{mg} / \mathrm{L}$ induced surgical anesthesia in 6-8 min, lasting $15-20 \mathrm{~min}$. The fishes were put directly into the aerated anaesthetic solution and sometimes the anesthesia was repeated three or four times without apparent damage to the animal.

The pattern of analgesia/anesthesia were comparable in the three fish species. Results are summarized in Table 1.

Table 1. Anesthesia or analgesia in Antarctic fishes (Notothenia neglecta, N. rosii, Trematomous bernachii) with ketamine, thiopental, fentanyl and benzocaine - Drugs were added to marine aerated water.

\begin{tabular}{llll}
\hline \multicolumn{1}{c}{ Drug } & \multicolumn{1}{c}{ Dose } & \multicolumn{1}{c}{ Anesthesia } & \multicolumn{1}{c}{ Analgesia } \\
\hline Ketamine (5)* & $15 \mathrm{mg} / \mathrm{L}$ & No anesthesia. Sedation & Present. Duration 2-3h \\
\hline Thiopental (5) & $100 \mathrm{mg} / \mathrm{L}$ & Anesthesia lasting 3-4h & Absent \\
\hline Fentanyl (5) & $50 \mu \mathrm{g} / \mathrm{L}$ & No anesthesia & Present. Duration 2-4h \\
\hline Benzocaine (10) & $100 \mathrm{mg} / \mathrm{L}$ & $\begin{array}{l}\text { Anesthesia within 6-8 min, } \\
\text { lasting 15-20 min }\end{array}$ & Absent \\
\hline$*$ In parenthesis the number of experiments & &
\end{tabular}

* In parenthesis the number of experiments

\section{Discussion}

Anaesthetic drug MS-222 (tricaine methanesulphonate) has been successful to anesthetize Antarctic fishes (WELLS et al., 1984; RYAN, 1992). Looking for an efficient alternative to MS-222 and for easy available anaesthetic products, we studied ketamine, thiopental, fentanyl and benzocaine. Initial trials were carried out with each drug, in order to establish a dose that could be effective and not lethal. Since we have strict limitations of fish specimens, a number but just enough to a trustful response was used. The initial trial doses used were calculated after the efficacy to induce anesthesia in man (except benzocaine). We assumed that, being most Antarctic fishes quite sluggish, with low metabolic rates, they could be sensitive to drugs like fentanyl and ketamine known to be very effective anesthetics to elderly and children. Besides, we tried thiopental, a very powerful barbituric hypnotic, used to short lasting anesthesia in man and local anesthetic benzocaine, widely used to cause anesthesia of fishes of temperate waters. Results show that the Antarctic fishes were very resistant to the depressor action of the drugs, as compared to red blooded animals. To administrate the drugs, we choose to dissolve them in the same water to which the fish was acclimated, avoiding a stress due to handling. We avoided also the parenteral administration of the drugs.

Ketamine, in doses about 10 times higher than that used for man caused only a very slight sedation, but, on the other hand, caused a long lasting analgesic response. Analgesia was accepted after no reaction to painful stimulus, like inserting a needle into the muscle, in various sites of the body, from head to tail, transfixation and tweezing of the skin. However, this time, the fishes displayed the reflex of escaping at a touch stimulus. The efficacy of analgesia must be suggest to be tested in surgical procedures. BRUECKER and GRAHAM (1993) used ketamine to anaesthetise the fish Heros citrinellum using doses of $30 \mathrm{mg} / \mathrm{kg}$ by intravascular injection. Maybe such via and higher dose could be successful in anesthetising the Antarctic fish.

Fentanyl, in a comparable dose enough to induce deep analgesia, unconsciousness and profound respiratory depression in man $(50 \mu \mathrm{g} / \mathrm{kg})$ caused in the fish only a light sedation, no significant alteration of respiratory frequency, but an effective analgesia, quick in onset (10-15 $\mathrm{min}$ ) and long lasting (2.0-4.0 hours). The duration of analgesia was grossly evaluated and later accurate experiments must be performed.

Thiopental demonstrated to be very active in causing long lasting anesthesia and respiratory depression. As expected, no analgesia was observed, but on the contrary, the fish was hyperactive to pain during the induction phase. The fish was highly resistant to the drug, being necessary a dose over 30 times than that used as anesthetic to man. This dose is however lower than that used by HIKASA et al., (1986) to anesthetize the carp. However, the anesthesia is difficult to control, since the time in onset and duration varied greatly from one animal to another. One of them remained in a comatose state for four days. All the time, the respiration was kept depressed but regular. The fish started to react very slowly and at the 5 th day he was returned to his "home" aquarium, and could swim normally.

The resistance of the Antarctic fishes to depressors of the central nervous system was quite demonstrated. One could expect a delayed onset of 
responses, due to a low rate metabolic but not such a resistance to the anesthetic effect, since they are so sluggish animals, seeming naturally depressed. Analgesia without anesthesia was very evident with ketamine and fentanyl, at least after the stimulus used.

Benzocaine demonstrated to be the most efficient anesthetic agent to the Antarctic fishes. The onset and duration of anesthesia was quite longer than those expected in fishes of temperate waters and was very satisfactory for surgical procedures. The anesthesia could be repeated two or three times in a same fish with no sign of intoxication.

Thiopental, though secure, was not appropriate to anesthesia of Antarctic fishes, due to a not predictable onset of depressor response and to a too long lasting anesthesia.

Based in the present results, we can suggest that fentanyl or ketamine can be useful in association with anesthetics like benzocaine, providing a long lasting analgesia and some sedation previous and after the surgery. Maybe such association can diminish the stress induced to the animals either by handling and surgery or by the anesthesia itself.

\section{Aknowlwdgment}

We are grateful to Prof. Leimin Kou for her help in the English revision.

\section{REFERENCES}

BARHAM, W.T.; SCHOOMBEE, H.J. A comparison of the effects of alternating current electronarcosis, retified current electronarcosis and chemical anesthesia on the blood physiology of the freshwater bream Oreochromis mossambicus (Peters)-II. The effect on haematocrit, haemoglobin concentration, red cells count, mean cell volume, mean cell haemoglobin and mean cell haemoglobin concentration. Comp. Biochem. Physiol. 98 A:179-183, 1991a.

BARHAM, W.T.; SCHOOMBEE, H.J. A comparison of the effect of alternating current electronarcosis, retified current electronarcosis and chemical anesthesia on the blood physiology of freshwater Oreochromis mossambicus (Peters) -III. Effects on the plasma electrolytes $\mathrm{Ca}^{2+}, \mathrm{Na}^{+}$and $\mathrm{K}^{+}$and on the osmotic pressure of the blood. Comp. Biochem. Physiol. 100A:357-360. 1991b.

BRADLEY, H.; ANDERSON, T.A. Changes in blood metabolite concentrations in response to repeated capture, anesthesia and blood sampling in the golden perch, Macquaria ambigua. Comp. Biochem. Physiol. 103A:445-450, 1992.

BRUECKER, P.; GRAHAM, M. The effect of the anesthetic ketamine hydrochloride on oxygen consumption rates and behaviour in the fish Heros citrinellum (Gunther 1864) Comp. Biochem. Physiol. 104C:57-59, 1993.
CHIBA, A.; CHICHIBU S. High energy phosphate metabolites in loach (Cobitis biwae) during urethane anesthesia. Comp. Biochem. Physiol. 106C:87-91, 1993.

CHIBA, A.; HAMAGUCHI, M.; KOSAKA M.; ASAI T.; TOKUNO T.; CHICHIBU S.I. In vivo ${ }^{31}$ P-NMR analysis of the electric anaesthetised loach, Cobitis biswae. Comp.Biochem. Physiol. 97A:385-389. 1990a.

CHIBA, A.; HAMAGUCHI M.; TOKUNO, T.; ASAI T.; CHICHIBU, S. Changes in high-energy phosphate metabolites in loaches (Cobitis biwae) during 2phenoxiphenol anesthesia. Comp. Biochem. Physiol. 97C:183-186, 1990b.

CORNISH, I.M.E.; MOON, T.W. The glucose and lactate kinetics of American eels, Anguilla rostrata, under MS-222 anesthesia. J. Fish Biol. 28:1-8, 1986.

FREDERICKS, K.T.; GINGERICH, W.H.; FATER, D.C. Comparative cardiovascular effects of four fishery anesthetics in spinally transected rainbow trout Oncorhynchus mykiss. Comp. Biochem. Physiol. 104C:477-483, 1993.

GILDERHUS, P. A.; MARKING, L.L. Comparative efficacy of 16 anesthetic chemicals on rainbow trout. North Amer. J. Fish. Manag. 7: 288-292, 1987.

GINGERICH, W.H.; DROTTAR, K.R. Plasma catecholamine concentrations in rainbow trout (Salmo gairdneri) at rest and after anesthesia and surgery. Gen. Comp. Endocrinol. 73:390-397, 1989.

GRAHAM, M.S.; IWAMA, G.K. The physiologic effects of the anesthetic ketamine hydrocloride on two salmonid species. Aquaculture 90:323-332, 1990.

HANSEN, L.P.; JOHNSSON, B.S. Salmon ranching experiments in the River Imsa (Norway): effects of dip-netting transport and chlorobutanol anesthesia on survival. Aquaculture 74:301-306, 1988.

HIKASA, Y.; TAKASE, K.; OGASAWARA, S. Anesthesia and recovery with tricaine methanesulphonate, eugenol and thiopental sodium. Jap. J. Veter. Sci. 48:341-352, 1986.

HUNN, J.B.; GREER, I.E. Influence of sampling on the blood chemistry of Atlantic salmon. Progressive Fishculturist 53:184-187, 1991.

IWAMA, G.K.; McGEER, J.C.; PAWLUK, M. The effect of five fish anesthetics on acid-base balance, hematrocrit, blood gases, cortisol and adrenaline in rainbow trout. Can. J. Zool. 67:2065-2073, 1989.

JUAREZ-CASTRO, G.; LATOURNERIE-CERVERA, J.R.; OLVERA-QUEZADAS，H.; PEREZ-CRUZ, M.E.; RUBIO-RAMON, A. Stress and anesthesia with sodium bicarbonate on hybrids of tilapia of the genus Oreochromis (Pisces, Cichlidae). Rev. Invest. Mar. 10:41-50, 1989.

KIHATA, L.M.; COLLINS, J.G. Narcotic Analgesics on Anesthesiology The William \& Wilkins Co., Baltimore, 1982.

LAIDLEY, C.W.; LEATHERLAND, J.F. Cohort sampling, anesthesia and stocking density effects on plasma cortisol, thyroid hormone, metabolite and ion levels in rainbow trout, Salmo gairdneri Richardson. J. Fish Biol. 33:73-88, 1988.

LOSEY, G.R.; HUGIE, D. M. Prior anesthesia impairs a chemically mediated fright response in a gobiid fish. J. Chem. Ecol. 20:1877-1883, 1994. 
MATTSON, N.S.; RIPLE, T.H. Metomidate, a better anesthetic for cod (Gadus mohua) in comparison with benzocaine, MS-222, chlorobutol and phenoxyethanol. Aquaculture 83:89-94, 1989.

McFARLAND, W.N.; KLONTZ, G.W. Anesthesia in fishes. Federation Proceedings 28:1535-1540, 1969.

MITSUDA, H.; YSHIDA, Y.; YOSHIKAWA, H.; UENO, S. Effects of a high concentration of carbon dioxide on electrocardiogram in the carp, Cyprinus carpio. Comp. Biochem. Physiol. 91A:749-457, 1988.

MORALES, A.E.; GARCÍA-REJÓN, L.; De La HIGUERA, M. Influence of handling and/or anesthesia on stress response in rainbow trout. Effects on liver primary metabolism. Comp. Biochem. Physiol. 95A:87-94, 1990.

OLIVER, A.E.; DEAMER, D.W.; AKESON, M. Evidence that the sensitivity to steroid anesthetics appears late in evolution. Brain Res. 557:298-302, 1991.

ORSI, J.A.; SHORT, J.W. Modifications in electrical anesthesia for salmonids. Progr. Fish-culturist 49:144-146, 1987.

PHARMA, D.E.; CROUX, M.J. Benzocaine (ethyl-paminbenzoate) as an anesthetic for Prochilodus lineatus, Valenccienes (Pisces, Curimatidae). J. Appl. Ichthyol. 6:189-192, 1990.

PUCÉAT, M.; GARIN, D.; FRÉMINET, A. Inhibitory effect of anesthesia with 2phenoxyethanol as compared to MS-222 on glucose release in isolated hepatocytes from rainbow trout (Salmo gairdneri). Comp. Biochem Physiol. 94A:221-224, 1989.

QUINN, T.P.; KONECKI, J.T. Effects of anesthesia on the chemosensory behaviour of Pacific salmon. $J$. Fish Biol. 33:637-642, 1988.

RANDALL, D.J.; HOAR, W.S. Special Techniques. In: Fish Physiology (Hoar and Randall eds). Vol. VI, Chapt. 8, pp.511-527. Academic Press, New York, 1971

ROBERTSON, L.; THOMAS, P.; ARNOLD, C. R. Plasma cortisol and the secondary responses of cultured red drum (Sciaenops ocellatus) to several transportation procedures. Aquaculture 68:115-130, 1988.

RYAN, S. Susceptibility of the Antarctic fish Pagothenia borchgrevinki to MS-222 anaesthesia. Polar Biology 11, 583-589, 1992.
SPOTTE, S.; BUBUCIS, P.M.; ANDERSON, G. Plasma cortisol response of seawater-adapted mummichogs (Fundulus heteroclitus) during deep MS-222 anesthesia. Zool. Biol. 10:75-80, 1991.

STERRITT, D.A.; ELLIOT, S.T.; SCHMIDT, A.E. Electrical anesthesia for immobilizing adult Coho Salmon in freshwater. North Amer.J. Fish. Manag. 14:453-456, 1994.

TAKASE, K.; OGASAWARA, T.; OGASASAWARA, S.S.O. Anesthesia and recovery with tricaine methanesulfonate, eugenol and thiopental sodium in the carp. Jap. J. Veter. Sci. 48:341-352, 1986.

THOMAS, P.L. Plasma cortisol and glucose stress responses of red drum (Sciaenops ocellatus) to handling and shallow water stressors and anesthesia with MS-222, quinaldine sulphate and metomidate. Aquaculture 96:69-86, 1991.

WELLS, R.M.G.; TETENS, V.; DeVRIES, A.L. Recovery from stress following capture and anaesthesia of Antarctic fish: haematology and blood chemistry. $J$. Fish Biol. 25:567-576, 1984.

WINTERS, W.D.; FERRER-ALLADO, T.; GUZMANFLORES, C. The cataleptic state induced by ketamine: a review of the neuropharmacology of anesthesia. Neuropharmacol. 11:303-315, 1972.

YAGITA, K.; IKEDA, Y.S. The effects of central nervous system depressants on chromatic behaviour of tilapia (Oreochromis niloticus). Bull. Japan. Soc. Sci. Fish. 52:187-192, 1986.

YOKOHAMA, Y.; KAWAI, F.; KANAMORI, M. Effect of cold $\mathrm{CO}_{2}$ anesthesia on post-mortem levels of ATPrelated compounds, $\mathrm{pH}$ and glycogen in carp muscle. Nippon Suisan Gakkaishi 59:2047-2052, 1993.

YOSHIKAWA, H.; YOKOHAMA, S.; UENO, S.; MITSUDA, H. Changes of blood gas in carp, Cyprinus carpio anesthetised with carbon dioxide. Comp. Biochem. Physiol. 98A:431-436, 1991a.

YOSHIKAWA, H.; YOKOYAMA, Y.; UENO, S.; MITSUDA, H. Electroencephalograph spectral analysis in carp, Cyprinus carpio, anaesthetised with high concentrations of carbon dioxide. Comp. Biochem. Physiol. 98A:437-444, 1991b.

YOSHIKAWA, H.; KAWAI F.; KANAMORI, M. The relationship between the EEG and brain $\mathrm{pH}$ in the carp, Cyprinus carpio subjected to environmental hypercapnia at an anesthetic level. Comp. Biochem. Phyisiol. 107A:307-312, 1994 